\title{
DETERMINANTS OF USE OF FARM MECHANIZATION SERVICES AMONGST EMERGING FARMERS IN NORTH WEST PROVINCE OF SOUTH AFRICA
}

\author{
Khulekani Khumbulani Sithembiso Nxumalo ${ }^{1}$, Michael Akwasi Antwi ${ }^{1}$, \\ Theresa Tendai Rubhara ${ }^{1 凶}$ \\ ${ }^{1}$ University of South Africa, South Africa
}

\begin{abstract}
There are low levels of farm mechanization in South Africa despite government efforts to improve access to infrastructure and finance through the Comprehensive Agricultural Support Programme (CASP). The objective of this study is to assess the levels of mechanisation in the emerging sector and the determinants thereof. The sample size consisted of 163 randomly selected maize and sunflower emerging farmers in North West Province. Data was collected using a structured questionnaire. Descriptive statistics were used to assess level of mechanization and the Tobit regression model was used to analyze factors that influence usage of farm machinery. The study revealed that variables including land tenure $(p<0.05)$, financial assistance $(p<0.01)$, access to loans $(p<0.05)$, and accessibility to road infrastructure $(p<0.01)$ positively influenced usage of mechanization. In addition, the variable age $(p<0.01)$ had a negative statistically significant influence on farm mechanization. Based on the results of this study, it is recommended that the government should consider scaling up the CASP to finance more farmers and review its land reform policy to ensure ownership of land to more young smallholder farmers who can use mechanization services for efficient agricultural production.
\end{abstract}

Keywords: emerging farmers; equipment; agricultural production; mechanization

\section{INTRODUCTION}

Smallholder agriculture is considered one of the major drivers of agricultural and economic growth in Sub Saharan Africa (SSA). According to Cousins (2010) and von Loeper et al. (2016), smallholder farmers are efficient in agricultural production and have high potential of ensuring food security globally. The agricultural sector in South Africa consists on one hand of a welldeveloped commercial farming and on the other hand the subsistence farming outlets (Antwi et al., 2014). Commercial farming has a small number of operators, predominantly operated by white farmers (Senyolo et al., 2009), who usually employ a high level of sophisticated technology to produce large quantities of specialized commodities, adding value in some cases (Pote, 2008). Most modern farms and agriculture-related industries make good use of today's modern equipment as well as the principles of science and technology. On the other hand, subsistence-based production is more prominent in rural areas (Antwi et al., 2014; Mmbengwa et al., 2009), with a large number of smallholder farms predominantly managed by black farmers (Senyolo et al., 2009) producing in smaller quantities due to the inadequate use of sophisticated technology (Pote, 2008). These farms are characterized by lack of access to adequate market facilities, high labour-intensity, low farm

$\bowtie$ Theresa Tendai Rubhara, Department of Agriculture and Animal Health, University of South Africa, Unisa Science Campus, Private
Bag X6, Florida, Johannesburg, 17 10, South Africa, e-mail: theresarubhara@gmail.com, https://orcid.org/0000-0002-9964-1638 
capital investment and little division of labour (Khapayi and Celliers, 2016).

The Government of South Africa has put agricultural at the centre of rural development through its role in food security, rural income and employment creation (National Development Plan, 2011). In order to redress the imbalances of the apartheid era, the Land Reform and Distribution Programme (LRAD) was one of the programs introduced by the Government of South Africa focusing on restitution, land tenure reform and land redistribution. In 2009, the Department of Rural Development and Land Reform (DRDLR) of the South African Government did an evaluation of the implementation of land reform programmes since their inception. During such evaluation, it was revealed that most projects were not successful due to lack of adequate and proper post-settlement support (DAFF, 2012). In order to provide the much-needed support, the DRDLR introduced the Comprehensive Agricultural Support Programme (CASP). The CASP targeted projects acquired through restitution and redistribution programmes to address the challenges. The intention of the programme was to provide black farmers with social and economic infrastructure and basic resources; combat poverty, unemployment and income inequality; reduce current rural-urban migration; and complement programmes in the agricultural sector. One of the interventions of the CASP was to provide access to farm equipment for emerging maize and sunflower farmers in North West province. Agricultural credit to purchase inputs and small equipment was administered through the Land Bank (DAFF, 2012).

Though smallholder farmers in south Africa are not a homogenous group, the generalised definition of indigenous small-scale farmers was applied for targeting of the CASP. The smallholder were supposed to meet certain criteria to qualify for the financial assistance. Firstly, it was specifically for South African smallholder farmers who are beneficiaries of the land reform programme emanating from previously disadvantaged groups. Secondly the farmer should be at least twenty-one years. Finally, the gross farm income from the enterprise should not be more than 20000 per month or exceed the South African Revenue System (SARS) thresh hold of non-taxable income (DAFF, 2012). Other services available to emerging farmers under the CASP includes use of hired equipment for tillage, planting, weeding and harvesting of crops. Smallholder farmers who are prepared to progress towards commercialisation are called emerging farmers. Therefore, in the context of this research the terms smallholder and emerging farmers will be used interchangeably.

Despite such strong policy framework, the smallholder farmers in South Africa continue to rely on human labour for agriculture, just like their counterparts in other African countries (Salami et al., 2010; FAO and AUC, 2018). Khapayi and Celliers (2016), highlighted a lack of farming implements as one of the factors limiting emerging farmers to develop into commercial farmers. According to FAO (2013), $70 \%$ of the farmers in SSA cultivate 2 ha or less by hoe; implying low levels of mechanisation. As a result, most of the smallholder farmers remain subsistence oriented. The objective of the study is, therefore, to analyse the determinants of use of farm mechanization by smallholder farmers. This will help in providing evidence-based policy instruments to improve smallholder farm mechanization in South Africa.

\section{LITERATURE REVIEW}

Farm mechanization is defined as the use of implements and machinery to improve the productivity of farm labour, and of land (Sims and Kienzle, 2006). Farm mechanization can be applied in tillage, planting, cultivation, harvesting, and post harvesting activities. Mechanization is considered an important input in agricultural production as it increases timeliness of planting operations and cropping intensity thereby improve productivity (Verma, 2006). Furthermore, it reduces drudgery associated with farming activities, and improves the quality of work and products (Sims and Kienzle, 2006). Moloi (2011) stated that the shortage of access to equipment such as loading ramps and sale pens in livestock production in South Africa is one of the factors that have a negative effect on the ability of small-scale farmers to participate in high value output markets. According to Wanmali and Islam (1997), infrastructural development plays an important role in most rural development initiates and efforts should be made to avail basic infrastructure.

There are several theories explaining smallholder farmers' behavior. According to Umar (2013), economic theories on smallholder farmers production on their own fail to explain farmers decision making process as they tend to ignore the context. For instance, a partial 
Nxumalo, K. K. S., Antwi, M. A., Rubhara, T. T. (2020). Determinants of use of farm mechanization services amongst emerging farmers in North West province of South Africa. J. Agribus. Rural Dev., 2(56), 221-228. http://dx.doi.org/10.17306/J.JARD. 2020.01316

application of economic rational theory implies that if farmers act rationally agricultural productivity can be achieved through factor availability and introducing new technology (Umar, 2013). Application of the theory implies that farmers will always adopt use of machinery since they are economically rationale. However, Cousins (2010) warned against treating smallholder farmers as one homogenous group as they may have differences in ownership of farm assets and are subjected to different constrains. Taking that into consideration, the decision-making process of farmers subject to productive constraints as highlighted by De Janvry et al. (2002) was adopted. Consequently, the decision to adopt mechanization was modelled as being affected by human, physical and socioeconomic factors. This study therefore builds on available literature of factors affecting use of mechanization.

Kuwornu et al. (2017) used the Double Hurdle Model to analyze the determinants of access to mechanization for rice farmers in Ghana. They found size of land, access to credit and availability of farm machinery as some of the factors positively affecting mechanization. The results of the trio concurred with that of Rasouli et al. (2009) who used the Delphi technique and discovered that small farm size, and fragmentation of farms resulted in farmers not using machinery adequately in Iran. Land is an important fixed resource in agricultural production and the law of economies of scale apply to adoption of mechanization services, therefore, it is not profitable to use highly sophisticated machinery on very small pieces of land. In Nigeria, it was also noted that most of the smallholder farmers use partial mechanization, where the use of machinery is limited to tillage and harvesting, and as a result full economic returns of mechanization is not realized (Olaoye and Rotimi, 2010). For instance, farmers may use tractors for tillage and resort to human power for planting. Though they reduce labor costs and time for tillage, they would not be able to do timely planting operations. Land access and ownership in South Africa is unevenly distributed and the land reform has been dominating major political debates in the country for the past few years (Akinyemi et al., 2019).

Grabowski (1990) argued that any adoption of technology (including mechanization) should take into context the social structure to achieve maximum gains, therefore, developmental efforts such as farm mechanization would be fruitless where farmers face uncertainties over tenure ship of land. Access to agricultural finance ensures that farmers are able to purchase productive equipment and ease liquidity constrains associated with small business (Salami et al., 2010). In South Africa farmers may apply for credit in mainstream financial institutions such as banks. However, under the CASP, farmers received subsidised loans from the Land bank sponsored by the government for agricultural production activities (DAFF, 2012). Financial assistance in this context, relates to government loans whereas access to credit refers to other types of loans provided by mainstream financial institutions.

Human capital is also considered as one of the major factors in adoption of technology. The age of the farmer, household size, technical skills and training received are core elements of human capital which determine labor productivity when decisions to mechanize are considered (Olaoye and Rotimi, 2010). Gosh (2010) posited that older farmers are less likely to use machinery as they may lack appropriate technical skills needed to operate modern day sophisticated farm machinery. However, farmers who have received training in the use of machinery are likely to adopt mechanization in their farms. According to Kuwornu et al. (2017), households with many family members tend to use less mechanization services as family labour usually replace the activities carried out by the machines. The decision to use farm mechanization services is therefore a function of different socio-economic factors.

\section{MATERIALS AND METHODS}

\section{Data used}

The study was conducted in the North West Province of South Africa. The Province covers an area of approximately $116180 \mathrm{~km}^{2}$, with a population density of approximately 30 people per $\mathrm{km}^{2}$. The mid-year population estimate of Statistics South Africa (2012) puts the population of the North West at 3.858 million inhabitants. The Province is largely rural in nature, and approximately $66 \%$ of its population lives in non-urban areas (Statistics South Africa, 2012). The agricultural sector produces $13 \%$ of provincial GDP and provides jobs for $18 \%$ of the labour force. Cattle, sunflower seeds, groundnuts, maize and wheat dominate the agricultural sector (Balarane and Oladele, 2014). The population of this study consisted of 208 maize and sunflower farmers 
participating in the CASP. Out of the 208 farmers, 73 were not financially assisted and 135 were financially assisted (DAFF, 2012). The researchers used stratified random sampling to get a sample size of 163 farmers, consisting of 135 financially assisted and 62 farmers not financially assisted. Semi structured questionnaires which had been pilot tested and adjusted were administered through face to face interviews to collect data. The data collected included socio-economic characteristics of the farming households and use of machinery in crop production.

\section{Composite indices for usage of mechanization}

The Principal Components Analysis (PCA) was used to compute composite indices of mechanization index from the different mechanization classes as indicated in the questionnaire. This approach helps to capture the different dimensions of usage of mechanization adopted by households in a composite manner, bearing in mind the likely correlation that could exist among mechanization services. Following the identification of the indicators as explained above, PCA was employed. PCA is a data reduction method used to re-express multivariate data in fewer dimensions. The procedure transforms selected indicators into smaller components that capture most of the information (variation) in the original indicators (Rahman and Rahman, 2020). Application of PCA on the selected indicators would yield a series of components with the first component explaining the largest variance in the data and subsequent components explaining additional but smaller proportions of the variance in the original variables. It is this dependent variable that could be regarded as households' mechanization usage index. Accordingly, the dependent variable (PCA-based Mechanization usage index) was generated. Four mechanization indicators were used to compute the mechanization index. Following Rahman and Rahman (2020), in this study the mechanization index was computed as follows:

$$
\text { Mechanisation index }=\emptyset_{i}+\beta_{i} \sum_{n=1}^{c} N_{i r}+z_{v}
$$

Usage of mechanization services index was computed using usage of mechanization for: tillage (yes $=1$, $0=$ otherwise); processing (yes $=1,0=$ otherwise); planting (yes $=1,0=$ otherwise); and ploughing (yes $=1,0=$ otherwise). The usage of mechanization index variable computed was then used as a proxy in the Tobit Regression Modeling for factors that influence usage of mechanization.

\section{Tobit Regression Model- for examining determinants of mechanization among respondents}

The Tobit regression model was employed to examine determinants of mechanization after carrying out tests for multicollinearity and heteroscedasticity. The Tobit model was used because the dependent variables are truncated as latent variables (Greene, 2003). In this study, the mechanization index was the dependent variable and it was lower censored at zero and upper censored at four. Farmers who did not have any use of farm equipment in any of their agricultural activities of tillage, planting, harvesting and cultivation will have a zero value of the mechanization index. The Tobit model is the most common regression model appropriate for analysing dependent variables with upper or lower limits (Tobin, 1958). In this study, agricultural mechanization was modelled as the unobservable decision to mechanize.

The Tobit model is specified as:

$$
Y_{i}^{*}=\beta_{1}+\beta_{2} X_{i}+\varepsilon_{i}
$$

In this equation (2), $Y_{i}$ is the dependent variable representing the mechanization index, $\beta$ is the regression coefficient of the explanatory variables, $X_{i}$ is the vector of independent variables and $\varepsilon_{i}$ is a normally distributed error term. The model errors $\varepsilon_{i}$ are assumed to be independently, $\mathrm{N}(0, \sigma 2)$ distributed, conditional on the $X_{i}$. Additionally, a truncation in normal distribution is made at some threshold value that is often set at zero. In such a case, the model is defined as 1 if $Y_{i}^{*}>0$ and 0 if $Y_{i}^{*} \leq$ 0 .Tobit can also be used to model dependent variables where the cut-off value is different from zero, or where observations with large values are those not observed (Dinarte, 2010).

\section{The explanatory variables}

Table 1 shows the explanatory variables used for the modelling and the expected relationship. The choice of variables and the apriori expectation was informed by the literatures reviewed. 
Nxumalo, K. K. S., Antwi, M. A., Rubhara, T. T. (2020). Determinants of use of farm mechanization services amongst emerging farmers in North West province of South Africa. J. Agribus. Rural Dev., 2(56), 221-228. http://dx.doi.org/10.17306/J.JARD. 2020.01316

Table 1. Explanatory variables

\begin{tabular}{lcc}
\hline \multicolumn{1}{c}{ Description of variable } & Measurement & Hypothesis \\
\hline Age & $\begin{array}{c}\text { Number of years } \\
\text { Number of years }\end{array}$ & + \\
in school & + \\
Size of Household & Number of people & - \\
Title deed document & $1=$ Available & + \\
& $0=$ Not available & \\
Residing closer to farm & $\begin{array}{c}\text { Distance in Km } \\
\text { Training received }\end{array}$ & + \\
$\begin{array}{l}\text { Government Financial } \\
\text { assistance }\end{array}$ & $\begin{array}{c}\text { Amount received } \\
\text { in rands }\end{array}$ & + \\
Access to other credit sources & $1=$ Yes $0=$ No & + \\
Non-farm activity & $1=$ Yes $0=$ No & - \\
Membership of union & $1=$ Yes $0=$ No & + \\
Road Infrastructure & $1=$ Available & + \\
& $0=$ Not available & + \\
Technical skills & $1=$ Available & + \\
Membership to farmers & $0=$ Not available & + \\
organisation & $1=$ Yes $0=$ No & + \\
\hline
\end{tabular}

Source: own elaboration.

\section{RESULTS AND DISCUSSION}

\section{Usage and providers of mechanization services within farm}

Results of usage or adoption of mechanization services within farms are presented in Table 2. Respondents were asked to indicate whether they used mechanization services for tillage, planting, harvesting, and cultivation, as well as indicate the providers of such services. Farmers could use more than one service provider for a service. The results revealed that majority $(60 \%)$ were not receiving tillage services from government, $56 \%$ were not receiving planting services from government, $83 \%$ were not receiving harvesting services from government, and $72 \%$ were not receiving ploughing services from government. In terms of providing these services for their farms, the results revealed that $94 \%$ of farmers were making provisions for their own tillage, $88 \%$ were making provisions for planting, $88 \%$ were making
Table 2. Usage of mechanization and ways in which farmers access such services

\begin{tabular}{lcccccc}
\hline & \multicolumn{5}{c}{ Frequency of farmers using particular services } \\
providers $(\mathrm{N}=163)$ \\
Service & Government & $\begin{array}{c}\text { Private } \\
\text { (individual) }\end{array}$ & $\begin{array}{c}\text { Commercial } \\
\text { company }\end{array}$ \\
& Yes & No & Yes & No & Yes & No \\
Tillage & 66 & 97 & 153 & $10(6)$ & 27 & 136 \\
& $(40)$ & $(60)$ & $(94)$ & & $(17)$ & $(83)$ \\
Planting & 71 & 92 & 144 & 19 & 49 & 144 \\
& $(44)$ & $(56)$ & $(88)$ & $(12)$ & $(30)$ & $(70)$ \\
Harvesting & 27 & 136 & 144 & 19 & 28 & 135 \\
& $(17)$ & $(83)$ & $(88)$ & $(12)$ & $(17)$ & $(83)$ \\
Cultivation & 46 & 117 & 144 & 19 & 51 & 112 \\
& $(28)$ & $(72)$ & $(88)$ & $(12)$ & $(31)$ & $(69)$ \\
\hline
\end{tabular}

Multiple responses possible, therefore, the totals do not add up to sample size. Figures in parentheses represents percentage frequency.

provisions for harvesting, while $88 \%$ were making provisions for ploughing. Regarding receiving these services from commercial companies, the results revealed that $17 \%$ of farmers received services from commercial companies for tillage, $30 \%$ received services for planting, $17 \%$ received services for harvesting and $72 \%$ received services for ploughing.

\section{Factors that influence usage of farm mechanization in the study area}

Table 3 shows the results of the Tobit regression for factors that influence usage of mechanization services among respondents. The Chi square of the likelihood ratio is statistically significant $(p<0.01)$, showing that the model appropriately fits the data. The findings in Table 3 shows that age of farmers was negative and significantly affected usage of mechanization service $(p<0.05)$. This implies that one-year increase in the age of farmers reduces the index for mechanization usage by 0.02 . This could be attributed to the following reasons. Without mechanization, agricultural production would require menial labour and drudgery making agriculture less attractive to younger farmers. Older people may also be reluctant to switch from familiar farming practices to modern and improved technology associated with use of machinery, therefore, older farmers are less likely to 
Nxumalo, K. K. S., Antwi, M. A., Rubhara, T. T. (2020). Determinants of use of farm mechanization services amongst emerging farmers in North West province of South Africa. J. Agribus. Rural Dev., 2(56), 221-228. http://dx.doi.org/10.17306/J.JARD. 2020.01316

invest in mechanization services. This result is consistent with that of Nepal and Thapa (2009), who found that older farmers were less likely to commercialise and mechanize than their younger counterparts.

The results also revealed that having land use title document was positive and significantly related to usage of mechanization $(p<0.05)$. This implies that ownership of land enhances famers' usage of mechanization services. Famers' investment decisions may be affected if they are not sure of how long they would be allowed to use the land. Tenant cultivators are reluctant to make investments in land management if they do not secure land tenure rights, which makes them vulnerable to eviction by landlords or government (Shimelles et al., 2009). This finding emphasises the need for greater attention to be given in terms of land tenure system. This also indicates that government is doing well in terms of offering land tenure rights to land reform beneficiaries as it motivates them to invest in mechanization services on their farms.

The findings in Table 3 further indicates that financial assistance from government had a positive relationship with usage of mechanization services and was statistically significant $(p<0.05)$. This implies that a one rand increase in government loans enhances the usage of mechanization by an index of 0.89 . This may be attributed to the fact that when a project is funded by government sufficiently, it enables beneficiaries to purchase new equipment and cushions the farmers from liquidity constraints related to the costs of production inputs (Salami et al., 2010). In this study, financial assistance was provided by the government at low interest rate enabling emerging farmers to participate in use farm mechanization services.

Furthermore, the findings in Table 3 further demonstrates that access to credit had a positive relationship with usage of mechanization services and was statistically significant $(p<0.01)$. This implies that improvement in access to loans increases the usage of mechanization services. This is in line with Mottaleb et al. (2016) that credit play a role in farmers' decision to adopt a new technology, especially if the new technology requires higher fixed costs. Lastly, the findings in Table 3 indicate that access to road infrastructure had

Table 3. Tobit Regression results for factors that influence usage of mechanization services among respondents $(\mathrm{N}=163)$

\begin{tabular}{|c|c|c|c|c|}
\hline Mechanization usage index & Coefficient & Standard. error & $\mathrm{t}$ & $\mathrm{P}>|\mathrm{t}|$ \\
\hline Age & -0.0246926 & 0.0079695 & -3.10 & $0.002 * * *$ \\
\hline Level of education & 0.0483535 & 0.1195944 & 0.40 & 0.687 \\
\hline Size of household & 0.0703988 & 0.0494393 & 1.42 & 0.157 \\
\hline Title document & 0.7487489 & 0.3431477 & 2.18 & $0.031 * *$ \\
\hline Residing closer to farm & -0.3586815 & 0.4093312 & -0.88 & 0.382 \\
\hline Training received & -0.3110671 & 0.3484985 & -0.89 & 0.374 \\
\hline Financial assistance & 0.8861503 & 0.3626534 & 2.44 & $0.016^{* *}$ \\
\hline Access to loans & 0.9129118 & 0.2844325 & 3.21 & $0.002 * * *$ \\
\hline Non-farm activity & -0.4236696 & 0.2613479 & -1.62 & 0.107 \\
\hline Membership of union & -0.2356271 & 0.2231049 & -1.06 & 0.293 \\
\hline Road infrastructure & 0.8919213 & 0.3011102 & 2.96 & $0.004 * * *$ \\
\hline Technical skills & 0.2695417 & 0.1848337 & 1.46 & 0.147 \\
\hline Farmers' cooperative & -0.2303272 & 0.1793291 & -1.28 & 0.201 \\
\hline Constant & -1.536392 & 1.35178 & -1.14 & 0.258 \\
\hline
\end{tabular}

LR Chi2 $(13)=56.74 ;$ Prob $>$ Chi2 $=0.0000$; Pseudo R2 $=0.0954$.

*** Significant at $1 \%$; ** Significant at $5 \%$; Significant at $10 \%$. 
Nxumalo, K. K. S., Antwi, M. A., Rubhara, T. T. (2020). Determinants of use of farm mechanization services amongst emerging farmers in North West province of South Africa. J. Agribus. Rural Dev., 2(56), 221-228. http://dx.doi.org/10.17306/J.JARD. 2020.01316

a positive relationship with the usage of mechanization services and was statistically significant $(p<0.01)$. This implies that improvements in access to road infrastructure enhances the usage of mechanization services within farms. Ideally, use of farm machinery such as tractor and combined harvester would require road network such that they can be easily accessed from one farm to another or from hiring companies.

\section{CONCLUSION}

The study was designed to assess the socioeconomic factors affecting emerging farmers' decision to use mechanization services in the North West Province of South Africa. It was noted that farmers were using mechanization services for four main agricultural activities of ploughing, planting, harvesting and cultivation. The variables: title document, financial assistance, access to credit and road infrastructure were found to positively influence farm mechanization. Age of farmer on the other hand, negatively influenced use of farm machinery. Continuous support for emerging farmers through financial assistance and loans should be provided so that farmers are motivated to use machinery and increase their land and labor productivity. The youth should be encouraged to engage into farming activities as they are able to use more sophisticated machinery required to increase agricultural productivity in the smallholder sector. The government should review the land reform policy in South Africa to provide ownership and longterm tenure ship of land to the previously disadvantaged groups especially the young people who have the potential to mechanise and produce efficiently.

\section{REFERENCES}

Akinyemi, B.E., Mushunje, A., Sinett, D. (2019). Land ownership and usage for agriculture: Empirical evidence from South African Living Conditions Survey. Cogent Soc. Sci., 2(1), 1663691. https://doi.org/10.1080/23311886.20 19.1663691

Antwi, M.A., Mazibuko, N.V.E., Chagwiza, C. (2014). Determinants of smallholder cattle farmers' access to highvalue cattle markets in the Ngaka Modiri Molema District, South Africa. Ind. J. Anim. Res., 51(4), 764-770. DOI: 10.18805/ijar.v0i0f.3804

Balarane, A., Oladele, O.I. (2014). The impact of irrigation farming on livelihood strategies among smallholder farmers in the North West Province, South Africa. Sust. Irr. Drain., 185, 223-234.

Cousins, B. (2010). What is a 'smallholder'?, Class analytical perspectives on small-scale Farming and Agrarian Reform in South Africa. PLAAS Working Paper, 16 Institute for Poverty Land and Agrarian Studies, University of the Western Cape.

DAFF (2012). Annual report. Department of Agriculture Forestry and Fisheries: Pretoria, South Africa

De Janvry, A., Sadoulet, E., Murgai, R. (2002). Rural development and rural policy, Handbook of Agricultural Economics. In: Gardner, B.L., Rausser G.C. (eds.), Handbook of Agricultural Economics ( $1^{\text {st }}$ ed., pp. 1593-1658). Elsevier.

Dinarte, A.J.C. (2010). Analysis of Brand Recognition Associated with the Texas Superstart and Earth-Kind TM Programs in Texas. Doctoral dissertation, Texas A\&M University. Lake, L. "Marketing Distribution", Available at: http://marketing.about.com/mbiopage.htm, 2007

FAO (2013). Agricultural Mechanization in Sub-Saharan Africa Guidelines for preparing a strategy. Integrated crop Management. Rome, Italy: Food and Agricultural Organization.

FAO, AUC (2018). Sustainable Agricultural Mechanization: A Framework for Africa. Addis Ababa, Ethiopia: Food and Agricultural Organization and African Union Commission.

Gosh, B.K. (2010). Determinants of Farm Mechanization in Modern Agriculture: A Case Study of Burdwan Districts of West Bengal. Int. J. Agric. Res., 5(12), 1107-1115. DOI: 10.3923/ijar.2010.1107.1115

Grabowski, R. (1990). Agriculture, Mechanization and Land Tenure. J. Dev. Stud., 27(1), 43-53; https://doi. org/10.1080/00220389008422181

Greene, W.H. (2003). Econometric analysis (5 $5^{\text {th }}$ ed.). India: Pearson Education.

Khapayi, M., Celliers, P.R. (2016). Factors limiting and preventing emerging farmers to progress to commercial agricultural farming in the King William's Town area of the Eastern Cape Province, South Africa. South Afr. J. Agric. Ext., 44(1), 25-41; http://dx.doi.org/10.17159/24133221/2016/v44n1a374

Kuwornu, J.K.M., Apios, E.K., Kwadzo, G.T.M. (2017). Access and Intensity of Mechanization: Empirical Evidence of Rice Farmers in Southern Ghana. Brazil. Arch. Biol. Technol., 60, 1-17. http://dx.doi.org/10.1590/1678-43242017160396

Mmbengwa, V.M. Gundidza, M., Groenewald, J.A., Van Schalkwyk, H.D. (2009). Factors affecting extension workers in their rendering of effective service to pre and post-settled farmers in Government initiated and 
Nxumalo, K. K. S., Antwi, M. A., Rubhara, T. T. (2020). Determinants of use of farm mechanization services amongst emerging farmers in North West province of South Africa. J. Agribus. Rural Dev., 2(56), 221-228. http://dx.doi.org/10.17306/J.JARD. 2020.01316

supported farming small, micro and medium enterprises. South Afr. J. Agric. Ext., 38, 1-14.

Moloi, M J. (2011). A Comparison of Socio-economic Characteristics that Determine the Farm Income of Emerging Livestock and Horticultural Farmers in South Africa. [Masters Thesis, University of Limpopo], UL Repository. http://ul.netd.ac.za/bitstream/10386/100/1/modis efinalthesis.pdf

Mottaleb, A.K., Krupnik, T.J. and Erensteina, O. (2016). Factors associated with small-scale agricultural machinery adoption in Bangladesh: Census findings. Journal of Rural studies, 46(2016), 155-168. https://doi.org/10.1016/j. jrurstud.2016.06.012

National development Plan South Africa Vision 2030. (2011). URL: https:/cisp.cachefly.net/assets/articles/attachments/ 36224_npc_national_development_plan_vision_2030_lo-res.pdf.

Nepal, R., Thapa, G. (2009). Determinants of agricultural commercialization and mechanization in the hinterland of a city in Nepal. App. Geog., 29(3), 377-389; https://doi. org/10.1016/j.apgeog.2008.12.002

Olaoye, J.O., Rotimi, A.O. (2010). Measurement of Agricultural Mechanization Index and Analysis of Agricultural Productivity of some Farm Settlements in South West, Nigeria. Agric. Eng. Int. CIGR Ejournal, XII (2010), Article 1372.

Pote, P.P.T. (2008). Technical constraints to smallholder agriculture: case study of Nkonkobe Municipality, Eastern Cape, South Africa [Unpublished doctoral dissertation] University of Fort Hare.

Rahman, A.S., Rahman, A. (2020). Application of Principal Component Analysis and Cluster Analysis in Regional Flood Frequency Analysis: A Case Study in New South Wales, Australia. Water, 12(3), 781. https://doi. $\operatorname{org} / 10.3390 /$ w12030781

Rasouli, F. Sadighi, H., Minaei, S. (2009). Factors Affecting Agricultural Mechanization: A Case Study on Sunflower Seed Farms in Iran. J. Agric. Sci. Technol., 11(1), 39-48.

Salami, O.A., Kamara, A.B., Brixiobia, Z. (2010). Smallholder Agriculture in East Africa: Trends, Constraints and
Opportunities. Working Paper Series 105, African Development Bank, Tunis, Tunisia.

Senyolo, G.M., Chaminuka, P., Makhura, M., Belet, A. (2009). Patterns of access and utilization of output markets by emerging farmers in South Africa: Factor analysis approach. Afr. J. Agric. Res., 4(3), 208-214. Article 5EF1B5E33901

Sims, B.G. and Kienzle, J. (2006). Farm power and mechanization for small farms in sub Saharan Africa, Agricultural and Food Engineering Technical Report. Food and Agriculture Organisation of the United Nations, Rome.

Shimelles, T.K.M. Zahidul, I., Tuulikki, P. (2009). Effects of land tenure and property rights on agricultural productivity in Ethiopia, Namibia and Bangladesh. Discussion Paper no 33. FAO. repository. Available: www.fao.org/filead$\mathrm{min} /$ user_upload/fsn/docs/HLPE/Discussion_Paper_33. pdf Acessed 21 July 2018

Statistics South Africa (2012). Statistical release P0301.4, Census 2011. Embargoed until: 30 October 2012 10:00. Statistics South Africa: Pretoria.

Tobin, J. (1958). Estimation of relationships for limited dependent variables. Econ. J. Econ. Soc., 26(1), 24-36.

Umar, B.B. (2013). A critical review and re-assessment of theories of smallholder decision-making: a case of conservation agriculture households, Zambia. Renew. Agr. Food Syst., 29(3), 277. https://doi.org/10.1017/ S1742170513000148

Verma, S.R. (2006). Impact of agricultural mechanization on production, productivity, cropping intensity, income generation and employment of labour. In: J. Singh (ed.), Stat. Agric. Mechan. India, 133-153. Delhi, ICAR.

von Loeper,W., Musango, J., Brent, A. and Drimie, S. (2016). Analysing challenges facing smallholder farmers and conservation agriculture in South Africa: A system dynamics approach. South Afr. J. Econ. Manage, Sci., 19(5), 747773 https://doi.org/10.4102/sajems.v19i5.1588

Wanmali, S., Islam, Y. (1997). Rural infrastructure and agricultural development in Southern Africa: A Centre-Periphery Perspective. Geog. J., 163(3), 